\title{
High-temperature Processing and Recovery of Decommissioned Electrochemical Cells and Batteries
}

\author{
Mária Čarnogurská 1 ** , Miroslav Príhoda ${ }^{2}$, Peter Kurilla ${ }^{1}$ \\ 1 Technical University, Faculty of Mechanical Engineering, Department of Power Engineering, Vysokoškolská 4, 04200 Košice, Slovakia \\ ${ }^{2}$ VŠB-TU Ostrava, Faculty of Materials Science and Technology, 17. listopadu 15, Ostrava, Czech Republic
}

\begin{abstract}
The present article describes the processing and recovery of decommissioned electrochemical cells and batteries by means of high-temperature melting in a reducing atmosphere. The experiment was carried out using two samples weighing 15 and $20 \mathrm{~kg}$. $\mathrm{CaO}$ was used as a slag-forming additive and carbon was used as a reducing agent. The results of the experiments carried out with an $80 \mathrm{kVA}$ plasma reactor showed that the decommissioned electrochemical cells and batteries may be disposed of using the plasma melting technology and the resulting product may be further recovered. The recovery rate for the non-ferrous metal of interest (cobalt) is approximately $95 \%$. The article also presents the chemical analyses of the formed alloy about weight of $3.7 \mathrm{~kg}$ in first and $5.6 \mathrm{~kg}$ in second experiment. The vitrified slag and fly ash analysis was also performed. The volume production of syngas was $12 \mathrm{~m}^{3} \cdot \mathrm{h}^{-1}$ with LHV from 2.7 to $3.4 \mathrm{MJ} \cdot \mathrm{m}^{-3}$.
\end{abstract}

Keywords: electrochemical cells, electrochemical batteries, high-temperature melting

\section{Introduction}

The European Waste Catalogue code of the accumulators subjected to the analyses discussed in the present article is 1606 05, Wastes not otherwise specified in the list - Batteries and accumulators [1]. Due to the fact that safe storage of electrochemical cells and batteries is problematic, they must be recycled or processed in a manner facilitating the recovery thereof. There are currently several known methods of disposal of electrochemical cells and batteries. The one that is most frequently applied is hydrometallurgical processing. However, also pyrometallurgical procedures are now being investigated. A pyrometallurgical method of waste recycling requires a relatively high amount of energy and high costs.

The first results of high-temperature processing of decommissioned LiMH cells and batteries [2] and other types of waste have already been published and they indicate the possibility to eliminate the problem associated with the storage of such wastes by applying the plasma melting technology; they also indicate that the materials and energy contained in such waste may be recovered. The above mentioned technology was applied in order to process, for example, the fly ash from the municipal waste $[3,4]$, electronic scrap [5], asbestos [6], or other waste materials, and subsequently use the separated waste components $[7,8,9,10,11]$.

Nowadays there has been concern regarding scarcity of some materials, such as cobalt, used in electrodes [12]. Cobalt is costly, and manufacturers are moving toward lower cost and higher energy density materials to reduce the cost of battery manufacturing, while also seeking to improve safety and performance. 
Therefore, cobalt-free materials will be more attractive and cost-competitive eventually [13]. On the other hand, recovering cobalt at end-of-life and returning it to new battery production has the potential to reduce battery life cycle impact $[13,14$, 15].

The article describes the results of the disposal of the mixed sample of electrochemical cells and batteries based on the use of the available environment-friendly techniques, the so called BAT (Best Available Techniques) in which the waste is disposed of and the contained materials and energy are utilised. The possibility of re-utilization of $\mathrm{Co}$ and other metal components represented in waste is discussed. The content of $\mathrm{Co}$ in the obtained alloy was more than $15 \%$, which, in view of increasing electromobility, can become an interesting secondary source of Co.

\section{Experimental section}

The experimental tests of melting and gasification were carried out using exhausted electrochemical cells and batteries taken from the separated collection of the commune systems in the Czech Republic. The chemical compositions of individual types of electrochemical cells and batteries are listed in Table 1.

Table 1: Average chemical compositions of primary and secondary electrochemical cells[10].

\begin{tabular}{|l|l|l|l|}
\multirow{2}{*}{ Component } & \multicolumn{4}{l}{ Content of component (\%) } \\
\cline { 5 - 5 } & Ni/Cd & \multicolumn{1}{l}{ Li-ion } & Ni/MH \\
\hline Steel & 35 & 22 & 20 \\
\hline $\mathrm{Li}$ & - & 3 & - \\
\hline $\mathrm{Mn}$ & - & - & 1 \\
\hline $\mathrm{Cd}$ & 15 & - & - \\
\hline $\mathrm{Co}$ & - & 18 & 4 \\
\hline $\mathrm{Ni}$ & 22 & - & 35 \\
\hline Zn & - & - & 1 \\
\hline Al & - & 5 & - \\
\hline Other metals & - & 11 & 10 \\
\hline Alkali & 2 & - & 4 \\
\hline Carbon & - & 13 & - \\
\hline Plastics & 10 & - & 9 \\
\hline Humidity & 5 & - & 8 \\
\hline Other non-metals & 11 & 28 & 8 \\
\hline
\end{tabular}

The molten waste consisted of the same amounts of monocells and compact batteries in plastic cases manufactured by various manufacturers. Therefore, it can be assumed that the sample prepared for the experimental purposes was representative and reflected the real average chemical composition of electrochemical cells and batteries from the separated waste. The waste was molten and gasified in an 80 kVA plasma reactor (Figure 1) and the output quantitative and qualitative data regarding the by-product of the melting process, i.e. syngas, were continuously evaluated. $\mathrm{CaO}$ was used as a slag-forming additive for the charge and carbon was used as a reducing agent.

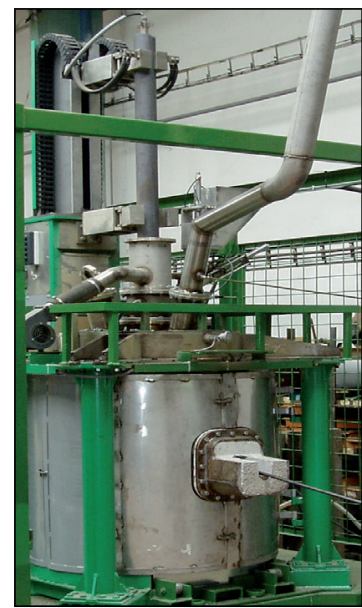

Fig. 1: Photo of a 80 kVA plasma reaktor [10].

During the melting process (at the temperature of approximately $1,600{ }^{\circ} \mathrm{C}$ ), plastics, paper and electrolytes contained in worn electrochemical cells thermally decompose into simple gas compounds and carbon, according to the general chemical reaction [10].

$$
\begin{aligned}
\mathrm{C}_{\mathrm{a}} \mathrm{H}_{\mathrm{b}} \mathrm{O}_{\mathrm{c}} \mathrm{Cl}_{\mathrm{d}} \mathrm{S}_{\mathrm{e}} \mathrm{N}_{\mathrm{f}(\mathrm{s})} & =\mathrm{xCO}_{(\mathrm{g})}+\mathrm{yH}_{2(\mathrm{~g})}+\mathrm{zN}_{2(\mathrm{~g})}+\mathrm{wH}_{2} \mathrm{O}_{(\mathrm{g})}+ \\
& +\mathrm{vS}_{2(\mathrm{~g})}+\mathrm{pCl}_{2(\mathrm{~g})}+\mathrm{rC}_{(\mathrm{s})}
\end{aligned}
$$

where $\mathrm{C}_{\mathrm{a}} \mathrm{H}_{\mathrm{b}} \mathrm{O}_{\mathrm{c}} \mathrm{Cl}_{\mathrm{d}} \mathrm{S}_{\mathrm{e}} \mathrm{N}_{\mathrm{f}}$ represents the general chemical formula of plastics, paper, and electrolytes; index (s) represents the solid phase; and $(\mathrm{g})$ represents the gaseous phase.

The above presented chemical reaction indicates that during thermal degradation of plastics, paper, and electrolytes the combustible syngas (SG) is formed. As for combustible gases, SG will contain mainly carbon monoxide and hydrogen. Such gas may primarily be used in the 
reduction of metal oxides and secondarily, after being purified, as the energy gas (free of dioxins, furans and $\mathrm{NO}_{\mathrm{x}}$ ) in cogeneration units with a micro turbine for the production of energy and heat. The syngas purification process increases the total costs for more extensive practical utilisation of high-temperature waste processing. In spite of the fact that this process is regarded as very costly, it facilitates environmentally friendly waste processing and material and energy recovery.

The chemical properties of electrochemical cells and batteries indicate that these types of waste form a multi-component heterogeneous mixture containing metals and their compounds, carbon, plastics, electrolyte and non-metals.

Thermodynamic calculations and considerations were made on the basis of the assumption that used electrochemical cells would be melted in a plasma reactor, without any previous treatment, in highly reducing environment. This means that the used electrochemical cells would be melted with carbon being used as a reducing agent for the reduction of metal oxides.

Another assumption was that metal compounds contained in electrochemical cells would thermally decompose when melted in a plasma reactor, according to the following reactions:

$\checkmark$ Nickelous hydroxide $\left(\mathrm{Ni}(\mathrm{OH})_{2}\right)$ decomposes at the temperature of $230^{\circ} \mathrm{C}$ to produce nickel oxide (NiO), according to the following reaction:

$$
\mathrm{Ni}(\mathrm{OH})_{2}=\mathrm{NiO}+\mathrm{H}_{2} \mathrm{O}_{(\mathrm{g})}
$$

When heated, manganese dioxide $\left(\mathrm{MnO}_{2}\right)$ decomposes according to the following reaction [9]

$$
\begin{aligned}
& \beta \mathrm{MnO}_{2}=525^{\circ} \mathrm{C}=\beta \mathrm{Mn}_{2} \mathrm{O}_{3}=925^{\circ} \mathrm{C}=\beta \mathrm{Mn}_{3} \mathrm{O}_{4}= \\
& =1.180^{\circ} \mathrm{C}=\gamma \mathrm{Mn}_{3} \mathrm{O}_{4}=\text { over } 1.180^{\circ} \mathrm{C}=\mathrm{MnO}
\end{aligned}
$$

On the basis of the comparison of the Gibbs free energy change per mole of reaction for oxides, fluorides and chlorides it may be assumed for aluminium and lithium compounds that at the temperature of $1873 \mathrm{~K}$ :

$\checkmark$ Aluminium chloride $\left(A I C_{3}\right)$ and lithium chloride (LiCl) would decompose to produce aluminium oxide $\left(\mathrm{Al}_{2} \mathrm{O}_{3}\right)$ and lithium oxide (Li20);

$\checkmark$ Lithium trifluoromethanesulphonate $\left(\mathrm{CF}_{3} \mathrm{LiO}_{3} \mathrm{~S}\right)$ would decompose to produce lithium fluoride (LiF-melting point: $845^{\circ} \mathrm{C}$; boiling point: $1,676^{\circ} \mathrm{C}$ ) which may have the effects of a fluxing agent in slag, similarly to calcium fluoride ( $\left.\mathrm{CaF}_{2}\right)$. Carbon, oxygen and sulphur would pass into syngas and carbon may function as a reducing agent.

In the production of metallic lithium applying the pyrometallurgical method, lithium oxide $\left(\mathrm{Li}_{2} \mathrm{O}\right)$ and lithium fluoride (LiF) are reduced by aluminium, at the temperature of $1,050-1,100{ }^{\circ} \mathrm{C}$, after adding calcium oxide $(\mathrm{CaO})$, to produce metallic vapours of lithium, according to the following reactions [16]:

$$
\begin{aligned}
& 3 \mathrm{Li}_{2} \mathrm{O}+\mathrm{CaO}+2 \mathrm{Al}=\mathrm{CaO} \cdot \mathrm{Al}_{2} \mathrm{O}_{3}+6 \mathrm{Li}_{(\mathrm{g})} \\
& 6 \mathrm{LiF}+4 \mathrm{CaO}+2 \mathrm{Al}=\mathrm{CaO} \cdot \mathrm{Al}_{2} \mathrm{O}_{3}+3 \mathrm{CaF}_{2}+6 \mathrm{Li}_{(\mathrm{g})}
\end{aligned}
$$

Subsequently, reduced lithium would concentrate mainly in fly ashes due to its low boiling point (1049.0 K).

Melted and reduced metals with high boiling points would then concentrate on the bottom of the plasma reactor as a separate liquid phase - a metal alloy. The main components of the reduced alloy, with regard to the chemical composition of electrochemical cells, would include $\mathrm{Fe}, \mathrm{Ni}$ and $\mathrm{Co}$, whereas other metals, such as $\mathrm{Cu}, \mathrm{Sn}$, Mn etc., would represent minor components of the metal alloy - they would be present in lower concentrations. The phase equilibrium diagrams for Fe-Ni and Co-Fe systems indicate that the reduction temperature should range from 1,500 to $1,600{ }^{\circ} \mathrm{C}$; at such temperatures, the Fe-Ni-Co alloy will be in the liquid phase. The melting point of the reduced Fe-Ni-Co alloy may decrease due to dissolution of carbon in the melt.

During the reduction-melting of electrochemical cells and batteries in a plasma rector, the following products are formed:

$\checkmark$ Alloy, located on the bottom of a plasma reactor, in which all metals with a high boiling point concentrate in a separate liquid phase, and are then reduced by carbon or metallically thermally, using Al and Li.

$\checkmark$ Slag in which all metal oxides with high affinity to oxygen and slag-forming additives concentrate and where unreacted metal oxides dissolve.

$\checkmark$ Fly ash, consisting of a mixture of mechanically pulled down charge particles and evaporated and condensed, or re-oxidised vapours of metals and their compounds that have low boiling points and high pressure of saturated vapours.

$\checkmark$ Syngas, consisting mainly of a mixture of nitrogen, carbon monoxide, and hydrogen with low concentrations of water vapour, sulphur and chlorine. Syngas is primarily produced during gasification of plastics, paper and electrolytes, but also during 
reduction of metal oxides, using the carbon that is added to the charge as a reducing agent.

The proportions of charge materials for individual experiments with melting and gasification of exhausted electrochemical cells and batteries $(\mathrm{ECaB})$ are summarised in Table 2. The table contains the data on the consumption of electric energy in a plasma reactor and the consumption of a plasma gas - nitrogen.

\section{Results and Discussion}

Table 3 contains the results of chemical analyses of the products obtained in the process of melting and gasification of electrochemical cells and batteries. The analysis results indicate that $\mathrm{Fe}, \mathrm{Ni}, \mathrm{Co}, \mathrm{Cr}, \mathrm{Cu}$ and $\mathrm{Mn}$ were reduced into the alloy.

The chemical compositions of slags produced in the process of melting and gasification of waste electrochemical cells and batteries are summarised in Table 4. It can be seen that the slag contained the concentrated elements with high affinity to oxygen, such as Al, Si, Mg and $\mathrm{Ca}$, as well as Fe in form of FeO oxides. The loss of Co in the slag was very low. In addition to unreduced $\mathrm{Fe}$, the slag also contained unsettled particles of FeCoNi alloy (Figure 2), representing the mechanical loss of this metal in the slag, as well as graphite. Slags with high mechanical losses must be recycled by melting or magnetic

Table 2: Basic data on the input materials for the process of $E C a B$ melting

\begin{tabular}{|lllllll|l|}
\hline Experiment & $\begin{array}{l}\text { ECaB } \\
(\mathrm{kg})\end{array}$ & $\begin{array}{l}\text { Slag-forming } \\
\text { additives } \\
(\mathrm{kg})\end{array}$ & $\begin{array}{l}\text { Reducing agent } \\
(\mathrm{kg})\end{array}$ & $\begin{array}{l}\text { Experiment duration } \\
(\mathrm{min})\end{array}$ & $\begin{array}{l}\text { El. energy consumption } \\
(\mathrm{kWh})\end{array}$ & $\begin{array}{l}\text { Plasma-forming } \\
\text { gas consumption } \\
\left(\mathbf{l} \mathrm{min}^{-1}\right)\end{array}$ \\
\hline 1 & 15 & 4.5 & 1.0 & 360 & 57.64 & 8.5 \\
\hline 2 & 20 & 9.0 & 4.0 & 420 & 61.78 & 8.5 \\
\hline
\end{tabular}

Table 3: Chemical analyses and weights of alloys obtained in individual experiments.

\begin{tabular}{|l|l|l|l|l|l|l|l|}
\hline \multicolumn{1}{l}{ ALLOY } & \multicolumn{7}{c}{ Chemical composition (\%) } \\
Experiment & FeCoNialloy $(\mathrm{kg})$ & $\mathrm{Fe}$ & $\mathrm{Ni}$ & $\mathrm{Co}$ & $\mathrm{Cr}$ & $\mathrm{Cu}$ & $\mathrm{Mn}$ \\
\hline $\mathbf{1}$ & 3.67 & 60.06 & 13.78 & 15.25 & 7.35 & 1.14 & 2.39 \\
\hline $\mathbf{2}$ & 5.61 & 45.70 & 6.82 & 29.51 & 3.32 & 12.86 & 1.66 \\
\hline
\end{tabular}

Table 4: Chemical analyses and weights of slags obtained by plasma melting.

\begin{tabular}{|l|l|l|l|l|l|l|l|l|l|}
\multicolumn{1}{c}{ SLAG } \\
Experiment & Slag $(\mathrm{kg})$ & $\mathrm{CaO}$ & $\mathrm{SiO}_{2}$ & $\mathrm{MgO}$ & $\mathrm{Al}_{2} \mathrm{O}_{3}$ & $\mathrm{Co}$ & \multicolumn{2}{c|}{ Fetotal } & \multicolumn{1}{c|}{$\mathrm{C}$} \\
\hline $\mathbf{1}$ & 5.50 & 13.83 & 14.40 & 0.27 & 50.28 & 0.29 & 2.85 & 16.26 \\
\hline $\mathbf{2}$ & 13.10 & 15.09 & 8.76 & 0.96 & 61.53 & 0.57 & 1.08 & 10.20 \\
\hline
\end{tabular}

separation of grind slags.

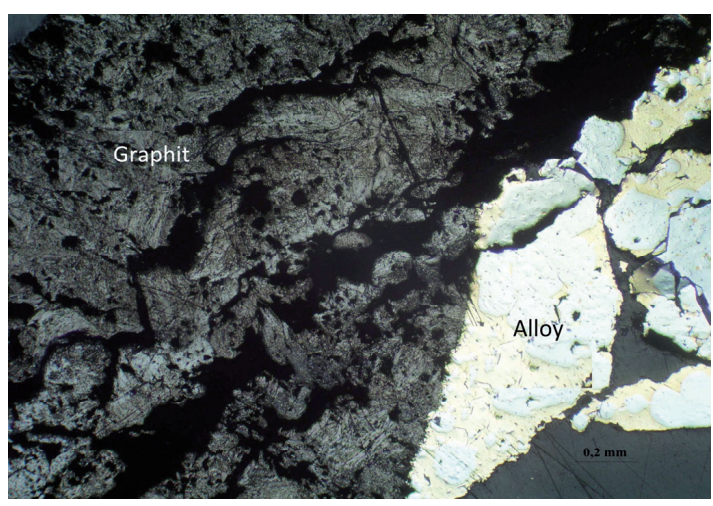

Fig. 2: Micro-image of the slag produced by plasma melting.

Fly ash was trapped in a cyclone separator located behind the reaction space in a plasma reactor where it was subsequently cooled to the temperature of approximately $160{ }^{\circ} \mathrm{C}$. The chemical composition of such fly ash is summarised for both experiments in Table 5. The chemical analyses indicate that the fly ash contained mainly $\mathrm{CaO}, \mathrm{MgO}, \mathrm{SiO}_{2}$ and $\mathrm{Al}_{2} \mathrm{O}_{3}$ oxides mechanically pulled down into the charge. The fly ash also contained the unreacted carbon and condensed vapours of $\mathrm{Na}, \mathrm{Ni}, \mathrm{Co}$ and Fe. Such fly ash may easily be recycled; this will increase the total recovery of metals.

Syngas (SG) produced during the melting process was purified as described in the experiments discussed in the literature [2]. Average concentrations 
Table 5: Chemical analyses and weights of fly ash.

\begin{tabular}{|c|c|c|c|c|c|c|c|c|c|c|}
\hline \multicolumn{2}{|c|}{ FLYASH } & \multicolumn{9}{|c|}{ Chemical composition (\%) } \\
\hline Experiment & $\begin{array}{l}\text { Fly ash } \\
\text { (kg) }\end{array}$ & $\mathrm{CaO}$ & $\mathrm{MgO}$ & $\mathrm{SiO}_{2}$ & $\mathrm{Al}_{2} \mathrm{O}_{3}$ & $\mathrm{Na}$ & $\mathrm{Ni}$ & Co & C & Loss of annealing \\
\hline 1 & 2.00 & 16.20 & 0.71 & 12.62 & 8.90 & 18.77 & 0.36 & 0.44 & 18.35 & 22.73 \\
\hline 2 & 3.50 & 17.47 & 0.69 & 10.18 & 11.62 & 22.75 & 0.58 & 0.57 & 10.83 & 24.30 \\
\hline \multicolumn{11}{|c|}{$\begin{array}{l}\text { Table 6: Average values of syngas components obtained by continuous measurements during the process of plasma melting an } \\
\text { gasification. }\end{array}$} \\
\hline \multicolumn{11}{|l|}{ SYNGAS } \\
\hline Experiment & Syn & as $\left(m^{3} \cdot h^{-1}\right)$ & $\mathrm{H}_{2}$ & & $\mathrm{CO}$ & & $\mathrm{CO}_{2}$ & & $\mathrm{CH}_{4}$ & $\mathrm{~N}_{2}$ \\
\hline 1 & 12 & & 5.53 & & 16.70 & & 1.27 & & 0.00 & 76.50 \\
\hline 2 & 12 & & 7.71 & & 20.20 & & 1.42 & & 0.00 & 70.67 \\
\hline
\end{tabular}

of the key syngas components identified by continuous chromatography measurements of $\mathrm{CO}, \mathrm{CO}_{2}, \mathrm{H}_{2}$, $\mathrm{N}_{2}$ and $\mathrm{CH}_{4}$ are summarised in Table 6.

Figure 3 presents the composition of the syngas produced in Experiment 1. The presented data depend on the period during which electrochemical cells and batteries, slag-forming additives and the reducing material were added into the charge.

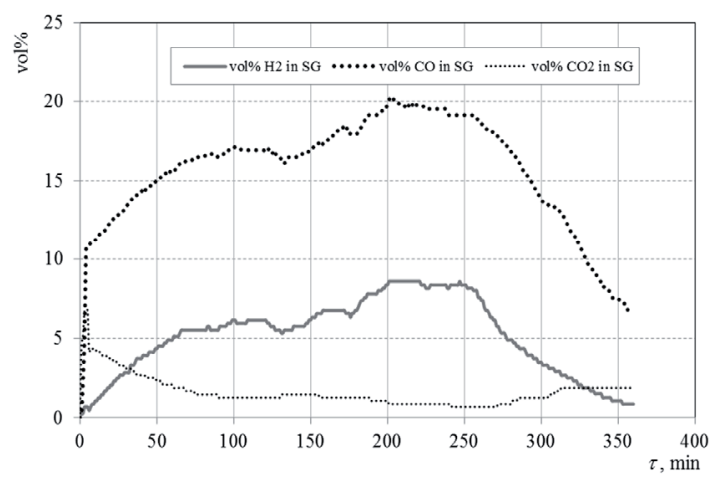

Fig. 3: Syngas composition during the first experiment.

The average LHV of SG for the entire period of Experiment 1 was $2.706 \mathrm{MJ} \cdot \mathrm{m}^{-3}$. Purified SG was burned together with natural gas in a cogeneration unit with the CAPSTONE C65 micro-turbine where electric and thermal energies were produced. The cogeneration unit was operated with a present required electric power of $55 \mathrm{~kW}$. The changes in the proportion of natural gas contained in the mixture burned during the experiment are shown in Fig. 4. The graph indicates that on average the syngas replaced $4.3 \%$ of natural gas. During the syngas incineration, also $\mathrm{CO}$, being the dominant component thereof, is liquidated.
The total recovery of the non-ferrous metal in question - cobalt into the metal phase was rather high. In Experiment 1, it was $94.59 \%$, and in Experiment 2 it was $95.76 \%$.

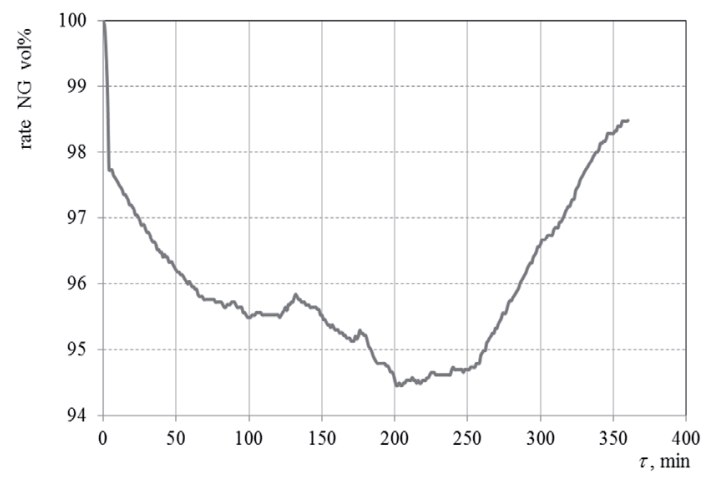

Fig. 4: Rate of NG in the mixture with syngas during Experiment 1.

\section{Conclusion}

The objective of the present article was to point out the possibility of high-temperature melting and recovery of decommissioned electrochemical cells and batteries. The secondary objective was to identify the recovery of cobalt into the metal phase and assess the energy gain from the utilisation of syngas within the total balance of the melting process.

During the experiment molten alloy, slag, fly ash and syngas were obtained. The molten Fe-Ni-Co alloy contained more than $15 \%$ Co, which shows the high cobalt recovery rate. The total recovery of the non-ferrous metal in question - cobalt into the metal phase was approximately $95 \%$. The slag contained the concentrated elements with high affinity to oxygen, such as $\mathrm{Al}, \mathrm{Si}, \mathrm{Mg}$ and $\mathrm{Ca}$, as well 
as Fe in form of FeO oxides. The loss of $\mathrm{Co}$ in the slag was very low. The LHV of the produced syngas is not very high with regard to its composition; it is approximately $3 \mathrm{MJ} \cdot \mathrm{m}^{-3}$. Nevertheless, in the operation of a micro-turbine, syngas may replace more than $4 \%$ of natural gas. A disadvantage of simple pyrometallurgical processes is that all of the components of the waste are melted; however, extraction and separation of several elements may require complicated additional treatments [17]. The high temperature process is also more energy intensive compared to hydrometallurgical processes. Its environmental significance is justified only in preventing the waste storage with the aim of maximum recycling of the products obtained.

\section{Acknowledgments}

This article was prepared with the support from the grant projects VEGA no. 1/0108/19 and SP2019/74-FMT VŠB TUO.

\section{References and Notes}

[1] HILTI Li-ion Batteries BU Measuring, wording 2.13, 8.8.2017, https://www.hilti.sk/medias/sys__ master/documents/ hc1/9239705714718/LI-ION-BATTERIES-It-100Wh-BU-M-SKIBD-WWI-00000000000004314776-000.pdf, 2018.

[2] Čarnogurská M., Lázár M., Kurilla P., Brestovič T., Jasminská N., Lukáč P., Dobáková R. (2018). Vysokoteplotné spracovanie a zhodnocovanie vyradených elektrochemických článkov [High-temperature processing and recovery of rejected electrochemical cells and batteries], WASTE FORUM, 2, 255.

[3] Lázár M., Lengyelová M., Imriš I. (2014) Vitrification of fly ash from incineration of municipal waste in a plasma reactor, Chem. listy 108, 543.

[4] Čarnogurská M., Lázár M., Puškár M., Lázárová M., Širillová L’. Václav J. (2015). Measurement and evaluation of properties of MSW fly ash treated by plasma, Measurement 62, 7 .

[5] Lázár M., Imriš I., Lázárová M., Horbaj P. (2015). Pyrometallurgical processing of electronic waste by plasma technology, Chem. listy 109, 543.

[6] Lázár M., Čarnogurská M., Brestovič T., Jasminská N., Bednárová L., Kmetová L., Jezný T. (2016). High-Temperature Processing of Asbestos-Cement Roofing Material in a Plasma Reactor, Pol. J. Environ. Stud. 25, 2027.

[7] Honus S., Kumagai S., Fedorko G., Molnár V., Yoshioka T. (2018). Pyrolysis gases produced from individual and mixed PE, PP, PS, PVC, and PET_-Part I: Production and physical properties, Fuel 221, 349

[8] Krzyżyńska R., Hutson N. D., Zhao Y., Szeliga Z., Regucki P. (2018). Mercury removal and its fate in oxidant enhanced wet flue gas desulphurization slurry, Fuel 211,876.
[9] Sevrjukov N. N., Kuzmin B. A., Čeliščev J. V. (1958), Obecné hutnictví [General metallurgy]. SNTL Praha.

[10] Kurilla, P. (2012). Dissertation work. TUKE, Košice

[11] Vlček J., Velička M., Klárová M., Burda J., Ovčačíková H., Topinková M., Jančar D. (2018). Development of parameters of slags from ladle metallurgy during their primary treatment, WASTE FORUM 11, 359.

[12] Larcher D., Tarascon J.-M. (2015). Towards greener and more sustainable batteries for electrical energy storage, Nat. Chem. 7 (1), 19.

[13] Ding Y., Cano Z. P., Yu A., Lu J., Chen Z. (2019). Automotive Li-lon Batteries: current status and future perspectives, Electrochem. Energy Rev. 2, 1.

[14] Wang X., Gaustad G., et. al. (2014). Economic and environmental characterization of evolving Li-ion battery waste stream, J. Environ. Manage. 135, 126.

[15] Arbabzadeh M., Lewis M. G., Keoleian A. G. (2019). Green principles for responsible battery management in mobile applications, J. Energy Stor. 24, 100779.

[16] Kunhalmi, G. (1990). Hutnictvo lahkých kovov. ES VŠT v Košiciach.

[17] Chang-Heum J., Seung-Taek Myung. (2019). Efficient recycling of valuable resources from discarded lithium-ion batteries, J. Power Sources 426,259. 